Ewa CIEŚLIK, PhD

Poznan University of Economics

e-mail: ewa.cieslik@ue.poznan.pl

DOI: $10.15290 /$ ose.2016.05.83.01

\title{
WHAT DEVELOPING COUNTRIES CAN LEARN FROM THE ASIAN EXPERIENCE: SELECTED ASPECTS OF THE SIGNIFICANCE OF OUTGROWER SCHEMES FOR ECONOMIC DEVELOPMENT ${ }^{1}$
}

\begin{abstract}
Summary
The article provides a study of the most important literature on the rural development in Asian developing countries in terms of arrangements between a farmer and a company. The review of the theoretical aspects of outgrower schemes is the background to comparative analysis of smallholders' contract in Eastern and Southern Asian developing countries. The paper discusses the potential results of these schemes, especially in relation to the economic development. The article addresses the significance of outgrower schemes in the light of increasing welfare of participants as well as potential disadvantages and barriers.
\end{abstract}

Key words: outgrower schemes, Asian developing countries, food supply chains, economic development JEL: Q13, Q18, O53

\section{Introduction}

Recently, product supply chains for agricultural commodity have become increasingly globalised and internationalised. The omnipresent delocalisation and fragmentation of production have not left this sector unaffected. Large food corporations and smaller firms are interested in more fragmented and diversified supply chains. Hence, they have focused on agriculture in developing countries. As a result, more smallholder farmers in the region of developing Asia (East Asia and South Asia) have begun to participate in global supply chains through applying outgrower schemes ${ }^{2}$. This vertical coordination

\footnotetext{
${ }^{1}$ The article is the result of the research project "Theoretical, institutional and empirical conditions and premises of economic potentials synergies of African countries and Polish economy" financed by the National Science Centre, Poland [DEC-2012/07/B/HS4/00743].

${ }^{2}$ Fragmentation of farms has been visible in developing countries. It is worth to mention that the average size of a farm in India was 2.2 hectare in 1970, but till 2011 it was one hectare. Chinese average farm size is 0.3 acres. Following African Development Bank statistics, generally in Africa an average farm size is 1.6 hectares, in Asia 2 hectares, in Europe 27 hectares, in North America 121 hectares, in South America 67 hectares, in Australia 3340 hectares [African Development Bank Group, 2014].
} 
is based on some popular economic theories such as: the life-cycle theory, transaction cost theory, or principal-agent theory. Generally, a number of theoretical approaches can be used to explain the linkages between growers and companies. Nevertheless, no conclusive theory or approach exist as yet [Rehber, 2007].

Arrangements between a farmer and a firm seem to be popular in many countries. Unfortunately, reliable data and information on their size in developing states still remain poor. Contrary to developed states, it is difficult to assess the size of outgrower schemes in developing world due to lack of data. In Brazil 70 per cent of poultry production, 40 per cent of pork, and 35 per cent of soybean were covered by outgrower scheme. In Mozambique all cotton and tobacco production was covered outgrower scheme in 2002 as well as in Zambia in 2006 [Sida, 2014]. In the United States outgrower scheme accounts for more than 40 per cent of food production. Sugar production via outgrower scheme accounts for 96 per cent, fruits 60 per cent, cotton 52 per cent, poultry 88 per cent, and port 61 per cent [USDA, 2014]. Contrary to developed states, it is difficult to assess the size of outgrower scheme in developing countries due to lack of appropriate data. The fact that a lot of contracts are informal makes this estimation almost impossible. There are some selected data, unfortunately the scale of outgrower scheme in Asia still has not been fully estimated. Plausibly, the proportion of agricultural production under outgrower scheme in developing countries, generally, may not exceed 15 per cent, but this remains a hypothesis [Oya, 2012]. Usually during estimation of the outgrower scheme share in agricultural production, we rely on the surveys cover the largest corporations, e.g. Nestle or PepsiCo or case studies. We leave alone smaller contract schemes between farmers and the local companies. According to "World Investment Report 2009" outgrower schemes activities by transnational corporations cover over 110 developing and transition economies [UNCTAD, 2009].

Outgrower scheme has existed for a long time. However, since the end of the $20^{\text {th }}$ century it has become more important, especially in developing countries. Developments in food industry, global value chains, and the process of globalisation, consumer demands, and technology in agriculture networks of supermarkets have accelerated the changes in production contracts patterns. Expansion of various forms of institutional solutions in developing countries as well as endemic imperfect market information on prices, costs, technology, financing, etc., combined with preferential market access to the most developed countries have led to great interest in analysed arrangements.

Generally, outgrower scheme consists of two or sometimes three parts of agreement. This type of production refers to the contractual agreement between corporation (firm, integrators) and farmers (growers). These two actors are essential. Occasionally this twosides agreement can be broaden by a third party such as schemes in different structures. Production contract may be understood as a farmer's commitment to provide an agricultural commodity of a type to the contractor. According to Glover and Kusterer, outgrower scheme or contract production can be simply defined as arrangements between a grower and a firms (exporters, processors, retail outlets, shippers) in which nontransferable contracts specify one or more conditions of marketing and production [Kusterer, Glover, 1990]. Each contract basically involves four elements: price, which is pre-agreed, required 
quality, quantity or acreage (minimum/maximum) of agricultural commodity and time when the delivery should be completed [Key, Rusten, 1999] ${ }^{3}$.

The main goals of this study are: 1) to describe the advantages and limitations of outgrower schemes in Eastern and Southern Asian developing countries and 2) to discuss the Eastern and Southern Asian experiences of outgrower schemes in terms of success and failure of these solutions. The paper is empirical. The study uses secondary sources of research material. These secondary sources include: literature in the area of outgrower schemes in Asian developing countries and available databases, mostly of international organisations, such as the World Bank, FAO, and UNCTAD. The applied research method is based on the detailed analysis of available literature and information on agricultural production agreements in the Eastern and Southern Asian developing nations. The serious obstacle to deepened research is the limited knowledge on the institutional arrangements and strategies adopted both by the farmers and the corporations. In the analysis, not only literature sources, but also press releases were used.

This paper consists of two parts that refer to the main goals of the article. The first part of papers concentrates on the outgrower schemes in the light of main advantages, drawbacks, problems and limitations for farmers and firms that are committed in this arrangement, in general terms. The author decided to apply more critical approach to describe production contract results. The next section presents outgrower schemes' impact on economic development. This part is an overview of studies of outgrower schemes that were evaluated as successful for farmers and characterized by the mixed results. In the conclusions, selected recommendations for further regulation in these specific areas of agricultural production in the light of the presented drawbacks are presented and some alternative solutions to production contracts are delineated.

\section{Outgrower schemes: risks and opportunities for their participants}

Outgrower scheme plays three main roles in the economy. First, these arrangements introduce element of predictability into production process and allow allocating resources with greater responsibility. Second, outgrower scheme allows both sides of agreement to share market risks. Third, participants of outgrower scheme are more motivated to achieve high performance [Milgrom, Roberts, 1992]. Were we acting in the world with perfect information where contracts were perfectly enforceable, the agreement between farmer and firm would specify exactly the action of both participants and could ensure efficient risk sharing. Seldom (almost never) do we act in presented environment. In the real world it is impossible to specify actions so as to ensure conformity with the agreement. In this context we often observe the so-called asymmetric information which in consequence may lead to moral hazard [Hueth et al., 1999].

Despite the fact that outgrower scheme fulfills the paradigms of free market, high efficiency, and accelerated economic growth - all neoclassical postulates - it does not mean

\footnotetext{
${ }^{3}$ In outgrower schemes we can usually find following provisions: the duration of the contract, the quality standards to be applied, quality control, quantity, the cultivation and raising methods required by the contractor, time of delivery, packaging, transport, price, technical assistance, procedures for paying farmers, insurance, procedures for dispute resolution [Bijman, 2008].
} 
that this solution is perfect and without any disadvantage. On the one hand, outgrower scheme may introduce significant improvements in agricultural productivity, reduce production risk to some extent, decrease the transaction costs and rise grower's incomes. On the other hand, outgrower scheme may make weaker farmers' bargaining power and increase risks by exposure to monopolistic markets, weak contract environments, and technologies that are not familiar [Kirsten \& Sartorius, 2002]. This point of view is proved by the empirical evidence that demonstrates the benefits of outgrower scheme are mixed for both: farmers and companies. This section presents critical view of outgrower scheme in general terms. This opinion may be represented by Redclift, who described transformations in agriculture in developing world using the following words: "The penetration of the South by new agricultural production technologies, marketing and outgrower scheme also severed to shift agriculture in parts of Latin America and Sub-Saharan Africa away from traditional, environmentally sustainable systems towards greater specialization and economic dependency" [Redclift, 1987].

Studies of outgrower scheme in developing countries have provided ambiguous empirical findings about the impact and offered different assessments of its role in the development process. There are studies that analyze the outgrower scheme impact regarding the stage of market development [Setboonsarng, 2008]. Some researchers perceive outgrower scheme essentially as a method adopting for shifting production risks to farmers and gaining control over growers' labour and land [Willson, 1986; Watts, 1992]. These studies have gathered a long list of negative impacts of outgrower scheme which are presented in table below (table 1). Some studies prove that even without violation of contracts, firms may use contracts to establish unequal relations with farmers [Singh, 2002]. For farmers, the increased income from outgrower scheme often proves to be short-term, due to market fluctuations [Willson, 1986; Little, Watts, 1994]. Among the most serious disadvantages of outgrower scheme is to rely on the exploitation of flexible and sometimes unpaid labour of the farming households, promotion exportorientated agriculture at the expense of subsistence agriculture and can threaten to food security [Little, Watts, 1994; Shiva, 1991]. Outgrower schemes may create negative externalities to rural communities as differentiation and disintegration [Singh, 2002]. The typical examples of environmental degradation due to outgrower scheme are overexploitation of groundwater, soil fertility decline, and pollution [Siddiqui, 1998]. Generally, outgrower scheme assumes that during negotiation meet two unequal partners. The potential farmer had lower bargaining power than agribusiness companies what indicates the possibility of being exploited by the corporations. Weaker farmers without any outside intervention have no ability to negotiate with wholesalers, processors etc. The form of these unequal positions at negotiating table very often left farmers from developing countries with two options: accepting or rejecting the offer. There are some concerns that outgrower scheme may create landlessness. There is also exclusion problem: firms may prefer to cooperate with larger farmers than smallholders [Minot, 2007].

The outgrower scheme has strong supporters. They argue that this arrangement can help to reduce market imperfections (imperfect information, price fluctuations etc.), decrease transaction costs significantly, shift technologies, knowledge and agro-services to farmers, raise incomes of both participants and promote economic development in 
rural areas [Grosh 1994; Key, Runsten 1999]. In the light of literature review we can find only few examples where companies preferred to contract with smallholders or where poor, small farmers faced no barriers to entry - in Chile, Mexico, Uganda, Kenya, and Senegal [Smalley, 2013]. Leave alone the ideological and methodological struggle among economic schools and thoughts, we can notice that the proponents of outgrower scheme have stemmed mostly from the new institutional economics and the opponents: from the political economics. The table below tries to combine the advantages and the disadvantages of outgrower scheme for farmers and companies (Table 1.).

TABLE 1.

\section{Advantages and disadvantages of outgrower schemes for farmers and companies: an overview}

\begin{tabular}{|c|c|}
\hline Advantages for a farmer & Disadvantages for a farmer \\
\hline $\begin{array}{ll}- & \text { Access to new reliable markets } \\
- & \text { Ability to purchase inputs } \\
- & \text { Protect against systematic loss } \\
- & \text { Access to credit and financial intermediation (sometimes } \\
\text { banks, microfinance institutions, and foundations } \\
\text { are involved) } \\
\text { - } \\
\text { Access to information, production and management } \\
\text { skill transfer, new technology, agro-services } \\
\text { (mechanization, transportation) } \\
-\quad \text { Ability to receive inputs (seeds, fertilizer) at lower } \\
\text { cost and extension services } \\
-\quad \text { Risk reduction through guaranteed prices } \\
-\quad \text { Decrease transaction cost } \\
-\quad \text { Higher value crops introduction means higher income }\end{array}$ & $\begin{array}{ll}- & \text { Risk of contract default } \\
- & \text { Risk of monoculture } \\
- & \text { Little (or lack of) bargaining power (inability to } \\
& \text { benefit from high prices) } \\
- & \text { Monopsonistic markets* } \\
- & \text { Traditional market linkages and traditional farming } \\
& \text { practices lost } \\
- & \text { Unsuitable technology and crop incompatibility } \\
- & \text { Manipulation of quotas and quality specifications } \\
- & \text { Poor or no income stream in first years for some crops } \\
- & \text { Indebtedness and overreliance on advances } \\
- & \text { Corruption } \\
- & \text { Delays in payment, inputs, or change in contract terms } \\
- & \text { Loss of flexibility } \\
- & \text { Rising inequality and landlessness } \\
- & \text { Promotion export-orientated agriculture at the expense } \\
& \text { of subsistence agriculture and can harm food security } \\
- & \text { Large-scale farmers are in favor }\end{array}$ \\
\hline Advantages for a company & Disadvantages for a company \\
\hline $\begin{array}{ll}- & \begin{array}{l}\text { Access to low-cost (even unpaid) labor, investment } \\
\text { opportunities }\end{array} \\
- & \begin{array}{l}\text { Risk reduction if outgrower schemes provides more } \\
\text { reliable source than open-market purchase }\end{array} \\
- & \begin{array}{l}\text { Risk reduction by eliminating responsibility for } \\
\text { production }\end{array} \\
- & \begin{array}{l}\text { Provision of more consistent quality than purchasing } \\
\text { on the open market }\end{array} \\
- & \text { Facilitation of trade standard requirements } \\
- & \text { Some crops considered more suitable for small-scale } \\
\text { - } & \text { production } \\
- & \text { Pecrease transaction cost } \\
- & \text { Overcoming land limitations } \\
- & \text { Promotion of farm inputs } \\
- & \text { Often avoid legal responsibility for pollution }\end{array}$ & $\begin{array}{ll}\text { - } & \text { Risk of contract default, side-selling or extra- } \\
\text { contractual marketing } \\
\text { - } & \text { Land availability constraints } \\
- & \text { Social and cultural barriers } \\
- & \text { Farmer discontent } \\
- & \text { Advances to farmers not repaid } \\
- & \text { Input diversion } \\
- & \text { Invernalization of support service costs } \\
& \text { transport infrastructure wasted } \\
- & \text { Staff underemployed }\end{array}$ \\
\hline
\end{tabular}

* where one buyer is purchasing the products of many producers within a certain geographical area Source: author's own study on the basis of [Minten, et al., 2009; Reardon, et al., 2009; Birthal, et al., 2005; Setboonsarng, 2008; Eaton, Shepherd, 2001; International Livestock Research Institute, 2007; Simmons, 2002]. 
In the outgrower scheme, as well as in every agreement, there rules a superior principle that both participants should obey: these relationships will be efficient only when the parties of the contract realize that they are better off by engaging in them. There must be real economic benefits for both participants; so the win-win situation should be realized. These benefits should be ensured (enforced) by the sustainable political, institutional and economical institutional architecture in a given country. Not only the institutions should be advanced, but also infrastructure, banking system, regulations and laws, etc. The process of price setting mechanism and price or credit agreement should be transparent as well as the conditions of contract should be understood to both sides, especially to farmers. There is a great role of farmers' organizations (associations) supported by the qualified advisors. Absence of accessible dispute resolution mechanism for both sides is still required. In many developing countries mediation centers have not been established and even if they exist they seldom offer rapid and costless hands-on services directed to smallholders.

Similar situation is observed in terms of legal advice companies. First, most lawyers perceive outgrower scheme as something new, so there is a problem with reliable expertise and experience. Second, contracts are not standardized, so advice on various and specific arrangements may be unprofitable for lawyers because farmers are not able to pay a lot, even many smallholders cannot afford this service at all. Third, lack of clear rights and obligations of both sides of contract. For example, in Zambia, smallholders have to sign an 18-page agreement which specifies their obligations excluding their rights. The company in return, 'endeavours to arrange' certain services but there is no corresponding clause protecting farmers in case of the companies default [Baumann, 2000].

\section{The empirics of outgrower schemes for economic development}

\subsection{The welfare impacts on farmers: general overview}

The literature on the impact of outgrower schemes on the economic development is poor. The paper summarizes the findings from empirical research and literature for developed and developing states separately. Presentation of the impacts on farmers in developing countries ignores Asian developing countries, because this group will be evaluated in the next section.

In spite of the fact that developed countries have introduced outgrower schemes long before developing nations, there is a small body of literature on the influence of outgrower schemes on the economic progress or just income. Hu [2012] indicated improvement in returns to soybean and corn farmers in the United States. Unfortunately, wheat farmers did not benefit from these schemes. Ahearn et al. [2002], Key and McBride [2007] convinced us in their research that an increase in outgrower schemes led to rising the productivity. Many authors [Hennessy, 1996; Key, 2013; Martin 1997] point out that many gains from the outgrower schemes may come from the risk of reduction and lower transaction costs. Nevertheless, there are surveys indicating that farmers in developed countries perceive outgrower schemes as an instrument that limits their independence [Schulze, Spiller, Theuvsen, 2006]. Paul et al. [2004], in turn, proved 
that the value of marketing and production contract were connected to greater productivity in the U.S. Key's and McBride's [2007] studies indicated that outgrower schemes in hog production led to raising productivity in the U.S.

More literature can be found in terms of outgrower schemes' impact on farmers in developing countries. Minot [2007] tried to indicate that outgrower schemes may assist smallholders in improvement in their productivity. Glover [1984] proved that outgrower schemes improve access to technology and markets. Their research included many developing countries. Olomola [2010], Ajo and Oyedele [2013] indicated that contracts farms were more efficient than non-contracts ones in Nigeria. Similar conclusions brought studies carried out by Nakano et al. [2014] in Tanzania. Many researchers have indicated connections between outgrower schemes and poverty alleviation in Africa. Minot [2011] and Adjognon [2012] have examined the general positive impact of outgrower schemes on poverty in Sub-Saharan Africa; Bolwig [2012] tested organic tropical products under outgrower schemes in Uganda; Porter and Phillips-Howard [1997] examined these contracts in Nigeria and South Africa; Minten et al. [2007] observed the technology diffusion to agriculture in Madagascar; Nsiku with Botha [2007] tested the tobacco sector in Malawi; and Vermeulen et al. [2008] examined over 60 case studies assessing the impact of African forestry on poverty reduction.

However, despite the fact that outgrower schemes can be intended to reduce poverty, this goal is not accomplished in every case and the role of contracts is limited [Salami et al., 2010; Mwambi et al., 2013; Freguin-Gresh et al., 2012]. The critics of the positive role of outgrower schemes in poverty reduction see in these arrangements the means of exploiting for minimum wages and taking control over small farms.

Generally, when we want to estimate outgrower schemes' results of economic development we can investigate the effect of these schemes on production and income. It means that we should answer following questions:

- Do outgrower schemes enhance production efficiency to non-contracted farmers?

- $\quad$ Is there any positive impact of outgrower schemes participation on smallholder income?

These questions can be answered using statistical and econometric methods or the performance indicators. Quite uncomplicated methods applying the indicators that evaluate the performance of the farming production. We can apply indicators that measure the influence of the outgrower schemes on the performance and compare the results to smallholders without production contract. This approach is based on the Tschirley et al. [2010] and Peltzer and Rotther [2013] methodology (Table 2.). 
TABLE 2.

Indicators for farming performance under outgrower schemes

\begin{tabular}{|l|l|}
\hline \multicolumn{1}{|c|}{ Type of indicator } & \multicolumn{1}{c|}{ Measured by } \\
\hline Quality & Level of contamination determined by expert opinion \\
\hline Access to credit & $\begin{array}{l}\text { Provision of input credits } \\
\text { Provision of investment credits }\end{array}$ \\
\hline Yield & Kilograms, liters etc. produced per ha, unit etc. \\
\hline Pricing & Farmers share of world market price \\
\hline Income & Net revenue of farmers \\
\hline Price stability & Qualitative assessment \\
\hline Environmental and social standards & Qualitative assessment \\
\hline
\end{tabular}

Source: on the basic of [Tschirley, 2010; Peltzer and Rotther, 2013].

\subsection{The welfare impacts on farmers in developing Asia}

In fact, the greatest success stories in agricultural development and poverty alleviation originated from the "green revolution". This wave covered Asia, especially China and India. A series of economic reforms accompanied 'green revolution'. During these reforms we observed significant changes in Asian agriculture. Agricultural yield increases were associated with new high-yielding crop varieties (e.g. rice and wheat), irrigation technologies, and use of inorganic fertilizers and pesticides. In parallel, the countries undertook heavy investment in rural infrastructure, extension, agricultural research, credit systems for input purchases, and interventions in input and grain markets. Generally, productivity has become the main factor of agricultural development [Dorwar et al., 2004]. This study divides the results of introducing outgrower schemes in developing Asia into two categories. The first group includes cases where these contracts were success and brought improvements in incomes or/and productivity. In the second group we will find cases with mixed results.

\subsubsection{Successful outgrower schemes in developing Asia}

Currently, outgrower schemes in developing Asia are perceived as an important tool against poverty [Hazell, et al., 2006]. There is clear empirical evidence that farmers under outgrower schemes in developing countries profit more than non-contract farmers ${ }^{4}$. Following some examples from developing Asia, Setboonsarng et al. [2006] examined rice contracts in Thailand, Setboonsarng [2006] carried his survey in Cambodia, Lao PDR and Myanmar on organic crops farms, IMF [2005] analyzed poultry and milk

\footnotetext{
${ }^{4}$ Contract farmers in Indonesia have higher incomes as much as 100 per cent than incomes of conventional farmers [The World Bank, 2007]. The organic basmati rice production in Thailand showed that smallholder incomes of contracted farmers were between 70 per cent and 100 per cent higher compared with non-contract farmers [Sriboonchitta, Wiboonpoongse, 2008].
} 
production in Bangladesh, Simmons et al. [2005] tested contract of poultry, seed maize, and rice in Indonesia, Singh [2006] characterized Thai and Indian agriculture, or Zhang [2012]: Chinese farming sector. Begum et al. [2012] indicated that contract smallholders were much more efficient than independent farmers in poultry sector in Bangladesh. Moreover, many studies pointed out farmers under outgrower schemes gained a higher productivity [Saigenji, Zeller, 2009; Miyatta et al., 2009].

All the above-mentioned works indicate that the outgrower scheme is implemented, inter alia, to absolutely reduce poverty. Many studies point out that the improvement in smallholders' income from outgrower schemes may come from three sources: access to market, access to technology, and access to other support, e.g. loans, subsidies, etc.

\subsubsection{Outgrower schemes in Asia with mixed results}

Despite the fact that one of the intentions of the outgrower scheme is economic growth and poverty reduction, this goal is not achieved in every case and the role of the outgrower scheme is limited [Salami, et al., 2010; Mwambi et al., 2013]. The critics of the positive role of outgrower schemes in poverty reduction see in these arrangements the means of exploiting for minimum wages and taking control over small farms.

Outgrower scheme projects have had mixed results for economic development. Success of outgrower scheme in Asia occurs for example in Vietnam where Luveco cooperates with farmers in fruits and vegetables delivery, India with PepsiCo and Nestle, in Thailand with soybean, baby corn or sweet corn, in Bangladesh with poultry for Aftab Bahumukhi Farms Ltd or cooperation of Bombay Sweets that buys potato and peanuts [Business Innovation Facility, 2012]. Zhang and Wu [2011] examined Chinese market and they indicated that where exists an open market the contract price is set by the market mechanism, the farmers under outgrower schemes do not obtain higher profits than non-contracted smallholders. Ito et al. [2012] showed that only smallholders in China may benefit from these contracts.

Nevertheless, there are many cases of outgrower schemes in Asia that can be defined neither as success nor as failure. They still have been discussed in the light of problems that the contractors should face. For example, benefits of outgrower scheme in East Java, Bali, and Lombok in Indonesia depend on farm size and other factors such as smallholder's age, education, and participation in farm groups. We can find similar conclusion in Kalamkar's [2012] study on India. Contracts increased returns to capital for the seed corn and broiler contracts, but not for the seed rice contract. All three contracts influenced the types of labor used; however, none of them influenced total farm employment [Simmons et al., 2005].

\subsubsection{Discussion}

As a whole, there is no agreement with regard to the role of outgrower schemes in promoting economic development in Southern and Eastern Asia. Empirical evidence presents ambiguous effects of outgrower schemes introduction on poverty alleviation 
in the analysed regions. Usually, farmers treat participation in contract production as a diversification strategy, which multiplies the sources of income and influences income. It seems to be the main reason of the debate concerning the point of the farmer's agreements in the light of the manipulation of contracts by companies and the growing social tensions generated by this externally induced change [Carney, Watts, 1990]. The conclusion from this part of analysis is that outgrower schemes should be assessed in a regional context.

There is a serendipitous aspect of the interdependence of poverty and outgrower schemes - increasing the likelihood of poor and small farmers being included in these schemes. There are three explanations of this phenomenon. First, public schemes are more likely to welcome smallholders than private ones when there are political objectives of inclusion and poverty reduction. It is quite a popular action that governments and donors subsidise the credit available to private companies when they decide to include farmers with small holding. Second, smallholders are generally perceived as partners without bargaining power. Nevertheless, they might be able to overcome the preference for contracting with larger farmers if they lobby through farmers' cooperatives, have local authority support or are represented within the scheme's management [Rotteger, 2004]. Third, poorer farmers are better able to participate when there are low or no barriers to entry.

It is worth presenting the latest evidence of small farmers' participation in outgrower schemes. The data on the degree of smallholders' participation in production contracts suggests that poorer smallholders are often excluded. For example, there are several studies that find a strong association between asset holdings, mostly land, geographic factors (such as market access and agro-ecological zone), and participation [Barrett 2008]. Though outgrower schemes generally improves the agricultural output of participants, some studies show that outgrower scheme mostly involves the better resourced, who have previously benefitted from e.g. public support [Freguin-Gresh et al., 2012]. A more optimistic interpretation of smallholders' participation in outgrower schemes is offered by researchers from the ADB. They have demonstrated that although smallholders are likely to be excluded in dualistic agrarian economies, there are numerous exceptions to this pattern [Readon et al. 2009]. Of the 35 successful cases on outgrower schemes assessed by Prowse [2012] in his study, 54\% were with smallholders, and 26\% were with a combination of both small and large farms.

\section{Conclusions}

The dynamic changes in agricultural value chains, the development of outgrower schemes, the rapid rise of large multinational retailers and global agro-exporters are the phenomena of contemporary agriculture. Similarly to the 'green revolution', outgrower schemes have affected agriculture in developing countries in varying degrees. Some regions benefit from this wave; some of them are omitted by this scheme. Many empirical studies of the effect of outgrower schemes participation have struggled to establish causality. Nevertheless, there is a number of cases which indicate that national context and 
domestic condition determine the success or failure of outgrower scheme. It means that it does not matter if we analyze Asian countries, but important are domestic conditions. Most of the studies suggest that in stable institutional surroundings participation in production contract may lead to higher levels of welfare and poverty reduction. Unfortunately, many poorer countries in developing Asia cannot establish stable institutional environment and cannot ensure for the smallholders positive results from outgrower schemes. Much more remains to be explored because we still know little about the role of the state in promoting contract production, the role of informal contracts in increasing welfare, or the importance of social conditions in positive results of outgrower schemes. The outgrower scheme continues to be perceived as a phenomenon which occurs in selected regions rather than a tendency in agriculture. The available data concern individual products or regions rather than countries or even continents as a whole.

This article has synthesised the findings from outgrower agreements in developing South and East Asian countries to form a conceptual framework of the determinants and dynamics of farmers' participation in production contracts. General conclusions suggest that there is a serious lack of data essential for conducting a complex comparison of the states of analysing regions. This analysis does not provide a comprehensive picture of the phenomenon of outgrower schemes in this region. However, this survey can be treated as an introduction to a complex comparative study of the Asian outgrower schemes and may spur further integrative analysis of the transformation in agriculture in developing countries, especially in Sub-Saharan Africa.

Areas for further research:

- a detailed analysis taking into account differences between various developing East and Southern Asian countries (reforms, stage of development etc.);

- a deepen overview of methods that can be useful in assessment of the relation between economic development and outgrower schemes introduction;

- $\quad$ impact of market volatility of agriculture products;

- $\quad$ understanding of the behavior and dynamics of different smallholders groups;

- $\quad$ long-term forecasts of price impact of farm products prices.

\section{References}

African Development Bank Group, 2014, African Development Bank Group, http://www.afdb.org/en/, (accessed: 01.08.2014).

Baumann P., 2000, Equity and Efficiency in Contract Farming: The Experience of Agricultural Tree Crops, "Working Paper Overseas Development Institute", Issue 139.

Bellemare M., Novak L., 2014, The Food Security Impacts of Participation in Agricultural Value Chains, s.l., Cornell IAD Seminar.

Bijman J., 2008, Contract Farming in Developing Countries: an Overview, s.1.: FAO Working Paper. 
Birthal P., Joshi P., Gulati A., 2005, Vertical Coordination in High-Value Food Commodities: Implications for Smallholders, "Markets, Trade and Institutions Division Discussion Paper International”, Issue 85.

Business Innovation Facility, 2012, Sustainable Contract Farming Initiative, s.1., Business Innovation Facility.

Dorwar A., Kydd J., Morrison J., Urey I., 2004, A Policy Agenda for Pro-Poor Agricultural Growth, "World Development", 32(1), pp. 73-89.

Eaton C., Shepherd A., 2001, Partnerships for Growth, FAO Agricultural Service Bulletin, Rome.

Hazell P., Poulton C., Wiggins S., Dorward A., 2006, The Future of Small Farms: Synthesis Paper, Rimisp-Latin American Center for Rural Development.

Hueth B., Ligon E., Wolf S., Wu S., 1999, Incentive Instruments in Fruit and Vegetable Contracts: Input Control, Monitoring, Measuring, and Price Risk, "Applied Economic Perspectives and Policy", 21(2), pp. 374-389.

IMF, 2005, IMF Staff Country Report 05/410 Bangladesh: Poverty Reduction Strategy Paper, IMF, Washington, D.C..

International Livestock Research Institute, 2007, Alternative Institutional Arrangements for Contract Farming in Poultry Production in Bangladesh and Their Impacts on Equity, s.l.: Bangladesh Agricultural University.

Key N., Rusten D., 1999, Contract Farming, Smallholders, and Rural Development in Latin America: The Organisation of Agro-Processing Firms and the Scale of Outgrower Porduction, "World Development", Issue 27, pp. 381-401.

Kirsten J., Sartorius K., 2002, Linking Agribusiness and Smal-Scale Farmers in Developing Countres: Is There a New Role for Contract Farming?, "Working Paper University of Pretoria", Issue 13.

Kusterer D., Glover K., 1990, Small Farmers, Big Business, s.l.: Palgrave.

Little P., Watts M., 1994, Living under Contract: Contract Farming and Agrarian Transformation in Sub-Saharan Africa, s.l.: University of Wisconsin Press.

Milgrom P., Roberts J., 1992, Economics, Organization and Management, Prentice Hall, New Jersey.

Minot N., 2007, Contract Farming in Developing Coutries: Patterns, Impact, and Policy, "Food Policy for Developing Countries: The Role of Government in the Global Food System".

Minten B., Randrianarison L., Swinnen J., 2009, Global Retail Chains and Poor Farmers: Evidence from Madagascar, "World Development", 37(11), pp. 1728-1741.

Mwambi M., Oduol J., Mshenga P., Saidi M., 2013, Does Contract Farming Improve Smallholder Farmers Income? The Case of Avocado Farming in Kenya, Hammamet, Tunisia, International Conference of the African Association of Agricultural Economists.

Narayanan S., 2012, Notional Contracts: The Moral Economy of Contract Farming Arrangements in India, "Indira Gandhi Institute of Development Research", Volume WP-2012-020.

Oya C., 2012. Contract Farming in Sub-Saharan Africa: A Survey of Approaches, Debates and Issues. Journal of Agrarian Change, 12(1), pp. 1-33.

Prowse M., 2012, Contract Farming in Developing Countries - A Review, "A Savoir", Issue February. 
Reardon T., Barrett C., Berdegué J., Swinnen J., 2009, Agrifood Industry Transformation and Small Farmers in Developing Countries, "World Development", 37(11), pp. 1717-1727. Redclift M., 1987, Sustainable Development: Exploring the Contradictions, Routledge, London. Rehber E., 2007, Contract Farming: Theory And Practice, The Lefai University Press, Hyderabad. Salami A., Kamara A. B., Brixiov Z., 2010, Smallholder Agriculture in East Africa: Trends, Constraints and Opprotunities, "Working Paper African Development Bank Group", Issue 105.

Setboonsarng S., 2008, Global Partnerships in Poverty Reduction: Contract Farming and Regional Cooperation, "Discussion Paper ADB Institute Tokyo", Issue 89.

Setboonsarng S., Leung P., Cai J., 2006, Contract Farming and Poverty Reduction: the Case of Organic Rice Contract Farming in Thailand, "ADB Institute Discussion Paper", Issue 49.

Shiva V., 1991, The Violence of the Green Revolution: ThirdWorld Agriculture, Ecology and Politics, Zed Books, London.

Sida, 2014, Contract Farming Offers Fresh Hope for Africa's Declining Agriculture, http://www.worldagroforestry.org/downloads/publications/PDFs/br07060.pdf (Accessed: 01.08.2014).

Siddiqui K., 1998, Agricultural Exports, Poverty and Ecological Crisis: Case Study of Central American Countries, "Economic and Political Weekly", 33(39), pp. 128-136.

Simmons P., 2002, Overview of Smallholder Contract Farming in Developing Countries, s.l.: University of New England.

Simmons P., Winters P., Patric I., 2005, An Analysis of Contract Farming in East Java, Bali, and Lombok, Indonesia, "Agricultural Economics", 33(3), pp. 513-552.

Simmons P., Winters P., Patrick I., 2005, An Analysis of Contract Farming in East Java, Bali, and Lombok, Indonesia, "Agricultural Economics", 33 (November), pp. 513-525. Singh S., 2002, Contracting out Solutions: Political Economy of Contract Farming in the Indian Punjab, "World Development", 33(39), pp. 1621-1638.

Singh S., 2006, Contract Farming and the State: Experiences of Thailand and India, s.l.: Kalpaz Publication.

Smalley R., 2013, Plantations, Contract Farming and Commercial Farming Areas in Africa: Comparative Review, "Land and Agricultural Commercialisation in Africa Workin Paper", Issue 055.

Sriboonchitta S., Wiboonpoongse A., 2008, Overview of Contract Farming in Thailand: Lessons Learned, “ADB Institute Discussion Paper”, Issue 112.

Stessens J., Gouët C., Eeckloo P., 2004, Efficient Contract Farming through Strong Farmers' Organisations in a Partnership with Agri-Business, "Hoger Institut", Issue May.

The World Bank, 2007, World Development Report 2008, The World Bank, Washington, D.C.

Tschirley D., Poulton C., Plerhoples C., 2010, Regulation of African Cotton Sectors: A Conceptual Approach, Insights in Best Practice, and Areas for Future Research, The World Bank, Washington, DC.

UNCTAD, 2009, World Investment Report 2009, UN, New York and Geneva.

USDA, 2014, http://www.usda.gov/wps/portal/usda/usdahome (accessed 01.08.2014). 
Watts M., 1992, Peasants and Flexible Accumulation in the Third World: Producing under Contract, "Economic and Political Weekly", 27(30), pp. 90-97.

Willson J., 1986, The Political Economy of Contract Farming, "Review of Radical Political Economics", 18(4), pp. 47-70.

Zhang Q. F., 2012, The Political Economy of Contract Farming in China's Agrarian Transition, "Journal of Agrarian Change", 12(4), pp. 460-483. 